\title{
The Discourse on the Praxis and Pragmatics of the Qur'an Retranslations in Turkish
}

\author{
Sema Üstün Külünk
}

\section{Introduction}

The Qur'an, holy book of all the Muslims around the world, has been partially and wholly translated into numerous languages since its revelation in Arabic in the $7^{\text {th }}$ century (Binark and Eren. As a country, where the majority of the population identifies as Muslim, Turkey has hosted a great number of retranslations of the Qur'an into Turkish since the early Republican era as well. More than five-hundred Turkish retranslations of the Qur'an have become available since 1923 till the present day (Üstün 297). This number includes various re-editions of the same Qur'an translations, annotated formats, simplified versions, and facsimiles.

As one of the most retranslated works in Turkish, Qur'an translations in Turkey constitute an intriguing site of research. Ongoing interest in these retranslations derives from a number of issues, including the sacred status of the source text, arguments over its untranslatability, the claimed deficiency of the human translator to render the words of the Holy creator, particular Arabicity of the source text vis-à-vis Turkish, and the hegemonic expertise claimed by faculties of theology vis-à-vis Translation Studies departments, creating a meta-narrative on the retranslations of the Qur'an in Turkish.

As is well-known "retranslation" prevailingly serves as an equivocal frame of reference as "the act of translating a work that has previously been translated into the same language" and "the result of such an act, i.e. the retranslated text itself" (Tahir Gürçağlar). This hypothesis explains governing premises of the translational act and product under different circumstances questioning the impact of the temporal, spatial, social, political and/or cultural contexts on the production of relative retranslations.

This study sets out to explore the particular discourse on the retranslations of the Qur'an in Turkish. As shall be further explored, each retranslated text has been released with a new argument to justify its necessity among the already existing Qur'an translations. In this regard, translational agents (i.e. the translators, editors, and publishers) of these retranslations put forth various claims to explain the motives behind their translations. The analysis of their statements reveals the differences in their approaches towards the conceptualization and instrumentalization of translation; and accordingly, shapes the meta-narrative on the Qur'an translations in Turkey. By exploring this unchartered territory of Turkish retranslations of the Qur'an, this study illustrates the religion-oriented context that marks the framing of the translations with a focus on paratextual elements (particularly book covers and prefaces) and with reference to respective social and political trajectories that governed the production of translations. 


\section{Questioning the Motives Behind Retranslation: Why is a text REtranslated?}

Studies on retranslation are mostly carried out to seek out the motives behind retranslations and the clues are often found in the context of the relevant retranslations (Tahir Gürçağlar). The "retranslation hypothesis" (Chesterman) can be stated as the dominant discourse when it comes to explaining the motives of retranslation. This "hypothesis" originates from an essay by Antoine Berman (Berman 1) and focuses on a discourse of "lack", which expresses "default, a deficiency, or decaying of first translations" (Massardier-Kenney 74). Retaining the language of lack, Lawrence Venuti also questions the motives behind retranslation, and concentrates on the "progress" stating that "retranslations are designed to challenge a previous version of a foreign text, they are likely to construct a denser and more complex intertextuality so as to signify and call attention to this competing interpretation" (28). However, this initial focus on the idea of improvement from one translation to another has been challenged with a number of counter-examples, revealing that retranslations do not always come closer to the source texts with new translations as claimed (Paloposki \& Koskinen). In a similar vein, Collombat notes that the reasons behind the "wave of retranslations" vary and in several instances, they are not concerned with improvement (Collombat 11).

\section{Exploring the Wave of Qur'anic Retranslations in Turkish}

Since its revelation in the $7^{\text {th }}$ century, the Qur'an has been translated into several languages, including Turkish numerous times. One may trace back Turkish translations of the Qur'an to different time spans, depending on how one defines the limits of Turkish. In other words, there are multiple 'first' translations of the Qur'an in the long history of the Turkish language. Determining which translation was/is the initial one depends on the set of criteria adopted for the periodization of Turkish language, including, for instance, Turkic languages spoken in the Anatolian principalities $\left(8^{\text {th }}-13^{\text {th }}\right.$ century), Turkish as spoken in the Ottoman period $\left(13^{\text {th }}\right.$ - early $20^{\text {th }}$ century), or the Turkish language in the Republican period (1923- onwards). This study mainly focuses on the translations of the Qur'an into Turkish printed in the Republican period after 1923 with due consideration of its organic roots with the Ottoman legacy.

The first Ottoman-Turkish translation of the Qur'an was published two years after the Tanzimat Period ${ }^{1}$ (1841). The title of this Turkish translation was Tefsir-i Tibyan [The exegesis of al-Tibyan] and was done by Debbağzade Muhammed Ayintabi in Cairo (Akdemir) in 1843. It was commissioned by Sultan Mehmet IV. Tefsir-i Tibyan was a Turkish translation of the Arabic commentary al-Tibyan fi Tafsir al-Qur'an [The exegesis of Qur'an by al-Tibyan] and it was reprinted eleven times in the late Ottoman period (Wilson). Following it, Tefsir'ul Mevakib Tercemet'ul Mevabib [The Exegesis of Mevakib and Translation of Mevahib] by Ambassador Ferruh Ismail Efendi was produced in 1865 (Hamidullah), which is also the year when the first press law entered into force, bringing strict rules for managements of the press (Berk 47). In the Ottoman period, Qur'anic

\footnotetext{
1 Also known as First Constitutional Era, Tanzimat refers to the reformative period characterized by modernization attempts between 1839-1876 in the Ottoman Empire.
} 
renderings in Turkish were produced only in the form of exegesis, and commentaries rather than translation proper.

Later in the Republican Era, in the absence of the office of the Sheikh'ul Islam ${ }^{2}$, three Qur'anic translations appeared in the market in 1924. The earliest of them was Süleyman Tevfik's (1865-1939) Kur'an-ı Kerim Tercümesi (Translation of the Noble Qur'an). This translation was followed by numerous other Turkish retranslations of the Qur'an in different forms and under varying titles. Figure 1 represents the increasing number of translations for each decade.

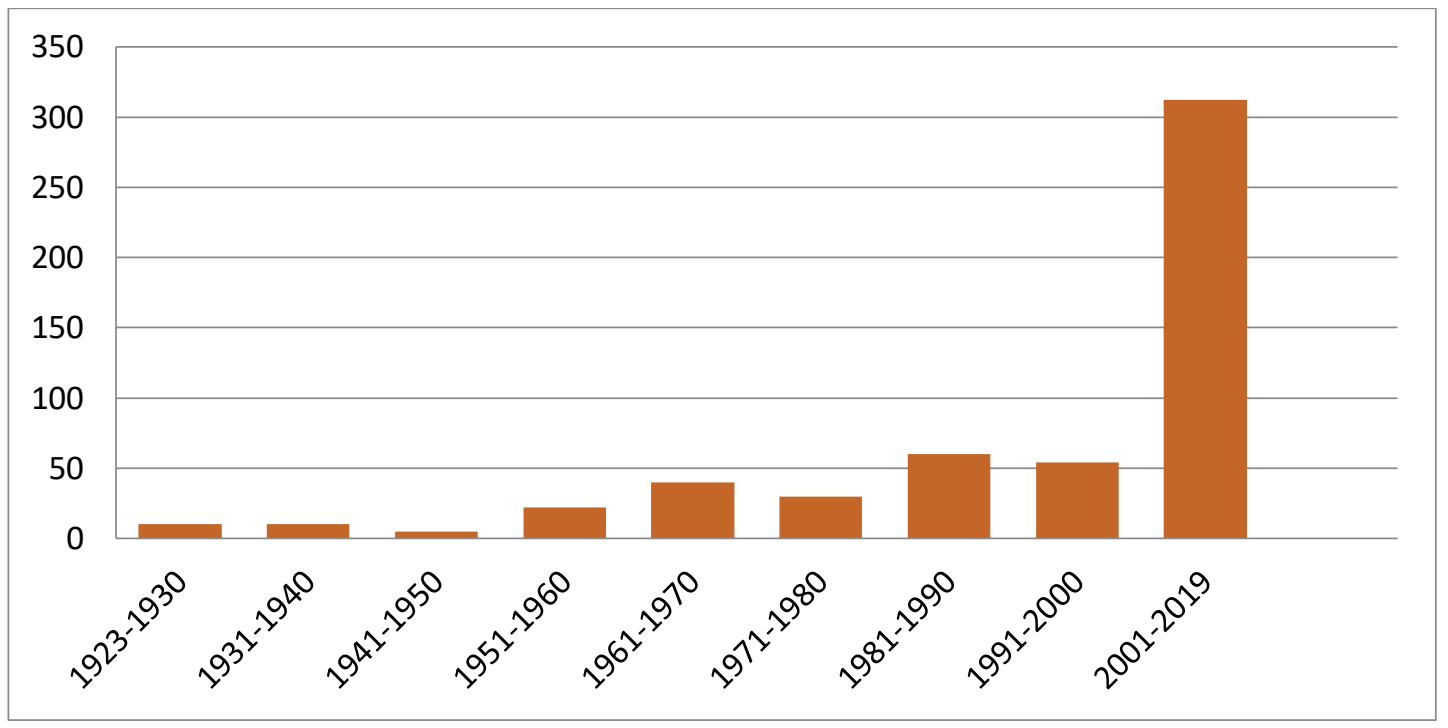

Figure 1 Qur'an Retranslations in Turkish between 1923-20193

\section{In search of a Qur'anic Retranslation Discourse: Praxis and Pragmatics of the Turkish Retranslations of the Qur'an}

The complex nature of Qur'anic retranslations in Turkish can only be understood with an initial exploration of the discourse over the Qur'an translations in the Ottoman period. One does not encounter any noteworthy reflections on the translation of the Qur'an in the Ottoman period until the $19^{\text {th }}$ century. There are several reasons behind the lack of accounts on Qur'an translations till that time. First, the ulama (religious and legal scholars in the Ottoman era) were the most influential group of the society, who led people' religious lives and practices. The interpretation of any Qur'anic issue was under their control, and the only Qur'anic reference books available then were Arabic exegeses. Thus, any individual interpretive attempt would receive a strong reaction and be interpreted as an act against their authority. Also, the rate of literacy was quite low, making written texts accessible to a very limited number of people; and hence, negatively affecting the demand for a translation. According to Ziya Paşa, the rate of literacy was estimated to be two percent in 1868 , and according to the State Institute of Statistics, it has varied between $8 \%$ and $10.6 \%$ in the

\footnotetext{
2 The title given to the grand religious authority, advising the sultan on religious matters, legitimizing government policies and appointing judges in the Ottoman period.

3 The figure is prepared on the basis of the archival data available in libraries such as ISAM, National Library, as well as prominent online bookshops such as Idefix, Kitapyurdu, etc.
} 
$19^{\text {th }}$ century (quoted in Berk 45). Furthermore, the language of instruction in institutions called madrasa (traditional-Islamic educational institutions in the Ottoman Empire) was Arabic (Wilson). Elucidating the issue from a different perspective, Ali Suavi drew attention to an Ottoman interculture (quoted in Paker), which viewed Arabic as an organic part of the language along with Persian and Turkish (Cündioğlu Türkşe Kur'an 158). Only with the nationalist turn and interest in the vernacular language, did people begin to view Arabic as "foreign" (Wilson 108), and remarkable cases of Qur'anic retranslations began to appear in Turkish after the establishment of the new Republican regime on 29 October 1923.

The year 1923 is defined as the beginning of Turkish society's transformation of, "a transformation from a multi-lingual and multinational Islamic regime under the Sultan-Caliph to a monolingual and one-national secular state" (Berk 93). The approach of the new state to religion was shaped in accordance with its reformist agenda, which also proved to be decisive in the production of Qur'anic renderings.

In 1924, the new government abolished the Islamic caliphate (3 March), closed the madrasas, which were opposed to the translation of the Qur'an into Turkish, and prohibited religious education (15 March) as well as the Sufi orders. Madrasas were replaced with schools for imams and preachers and a theology faculty was established at the University of Istanbul, therefore the control of the religious education passed to the Ministry of Education (McPherson 5).

In this context, the debut of the Turkish translations of the Qur'an sparked a hot debate on the translatability of the Qur'an, the necessity of the translation as well as the characteristics of the forthcoming retranslations. With "the spread of literacy via state schools, emergence of nationalism, print technology as well as intellectual currents" (Wilson 16), Qur'anic retranslations emerged as a topic for debate in the early Republican period. In this regard, the ideal of a Muslim society that can truly comprehend Islam emerged as the preliminary premise for Qur'an translations.

To shed light on this discursive narrative on Qur'anic retranslations in Turkish, I will concentrate on two types of material: quantitative data and qualitative statements. The first type of material refers to the changes in the number of retranslations of the Qur'an in different time spans. This numeric analysis concentrates on the impact of the temporal and spatial frameworks on the Qur'anic renderings. Namely, the chronological analysis divided into decades focuses on particular socio-political conditions of the relevant durations. The second type of material relies on the distinctive context of Turkish Qur'an translations as widely revealed in their paratexts (i.e. book covers, and prefaces in this case) (Genette), with particular references to the statements of respective translators. Qur'anic translations have been designated by different titles in Turkish. Among them three main terms come to the fore: tercüme [translation], meal [synopsis of meaning], and tefsir [exegesis]. In this study, I consider all of them as a (heterogenous) sum of Qur'an retranslations without delving into their translational differences (i.e. different translation strategies applied in these practices, such as literal translation, annotated translation, etc.). This bi-faceted analysis of the discourse on the translations of this religious text is motivated to demonstrate the 
social, political, and financial concerns governing the reproduction of a canonical work other than religious concerns, as one would initially expect.

\subsection{A Chronological Overview of the Qur'an Retranslations in Turkish}

This section examines the quantitative changes in the number of the retranslations of the Qur'an. This quantitative analysis is accompanied by an elucidation on the terminological diversity of the designation/labeling/titles of these Qur'an translations. The aim is to map any correspondences between the numbers of the retranslations and social, political, and economic changes in Turkey with a concentration on their impact on the discourse of Qur'an retranslations.

Prior to the involvement of the state, private publishers such as İbrahim Hilmi and Naci Kasım undertook some translations in the beginning of the Republican period (Cündioğlu Kur'an Cevirilerinin Dünyası 30). As mentioned before, the first translation in Turkish was Kur'an-ı Kerim Tercümesi [Translation of the Noble Qur'an] (1924) by Süleyman Tevfik (1865-1939) (Hamidullah and Yaşaroğlu). The publisher of this translation Naci Kasım also wrote an introduction to the translation explaining why he sponsored the translation:

It is impossible for those who do not know Arabic and Persian to understand the noble meaning of the Noble Qur'an that is the light of guidance of the civilized world, impossible to know its commands that guide the way. Though four noble works in Turkish have been published [...] these were written a century ago, and their archaic style and stilted expressions prevented the students from benefiting from them. (quoted in Wilson 423)

These introductory statements provide clues on the expected functions of Qur'an translations, explaining the motives behind the production of this and following retranslations. In this excerpt, concerns over understandability, accessibility and civilization are foregrounded. This translation received severe criticisms at its time, which were mainly published in Sebilürreşad, an influential journal of the period (Aydar 48). According to Wilson (2009), these reactions display the view of the devout intelligentsia of the time about the Qur'an translators, "who did not meet the conventional requirements of Islamic scholarly disciplines" (424). Furthermore, the advertisements for this translation in multiple newspapers and accompanying commercial images were regarded as disrespectful and scandalous for the Qur'an (Wilson 424).

In the same year, this translation was immediately followed by the second translation of the Republican period, Nur'ul Beyan [The Light of Explication] (1927) by Hüseyin Kazım Kadri (1870-1934) who used the pseudonym Şeyh Muhsini Fani (Erşahin 152). Hüseyin Kazın Kadri was a bureaucrat, politician and journalist with no competency in Islamic fields. This translation also provoked criticisms, including those by the head of the Directorate of Religious Affairs for its deficiency in Arabic language and fiqh (Islamic law) (Cündioğlu Kur'an Cevirilerinin Dünyası).

Furthermore, the language combination used in the translations of the time was not limited to Arabic-Turkish. There were also translations of the Qur'an produced by using a mediating 
language, resulting in "relay translations". As an example, Cemil Said, a government official, produced a Qur'an translation from French into Turkish in 1924 (Durmuş 145). Said's translation also invoked harsh criticisms. The title of this translation Türkşe Kur'an-ı Kerim [Turkish Qur'an] was deemed distorted and misguided (Durmuş 146). In addition, the educational and professional background of the translator was found inappropriate for translating the Qur'an. That the translation was a relay translation from an intermediary language rather than a direct translation, (i.e. it was not translated directly from the Arabic Qur'an but from Albert de BibersteinKazimirski's French Qur'an translation, which already had been in circulation for decades in Istanbul) also caused dispute. All three translations published in 1924 were received with disappointment and outrage by most of the devout intellectuals in Turkey (Wilson 421).

After these private initiatives, the state's involvement in the field of Qur'an translations was met with different reactions by different sections of the society. Kemal Karpat counts "the translation of the Qur'an into Turkish among the reforms of the long-term nationalization project" (282). The parliament decided to publish an official translation of the Qur'an and accordingly commissioned Mehmet Akif to produce the translation (tercüme) and Elmalılı Hamdi Yazır to produce an exegesis (tefsir) of the Qur'an in 1932. After Mehmet Akif's resignation from the duty, Yazir agreed to fulfill the project only on the condition that his translation would be called meal (Aydar 48), which he formulized and introduced as a translation postulate for an appropriate rendering of the Qur'an. As shall be elaborated below, the term would acquire wide acceptance and turn into an established Qur'anic term appearing in the titles of Qur'an translation in Turkish since then.

The early years of the Turkish Republic may be called "transformation years". It was the period when the newly founded secular state started carrying out several reforms to create a onenational and monolingual state from a formerly multi-lingual and multi-national society. In 1924, only a year after the foundation of the Republic, three Qur'an translations were published, all termed tercüme. Under the shadow of ongoing radical reforms of the new regime, Ibrahim Hilmi published Türkģe Kur'an-ı Kerim Tercümesi [Turkish Qur'an Translation] in 1926. It was prepared by a translation committee (Hamidullah 86). However, Osman Ergin maintains that this translation was in fact done by Zeki Megamiz, whose name was not revealed, as Megamiz was a Christian Arab. This was followed by Maani-i Kur'an-Kur'an-ı Kerim'in Türkse Tercümesi [The Meaning of the Qur'an- Turkish Translation of the Qur'an] by İzmirli İsmail Hakk1 in 1927. Figure 2 demonstrates the number of Qur'an retranslations produced in the early Republican era under different designations in Arabic script, which continued to be used until 1928. 


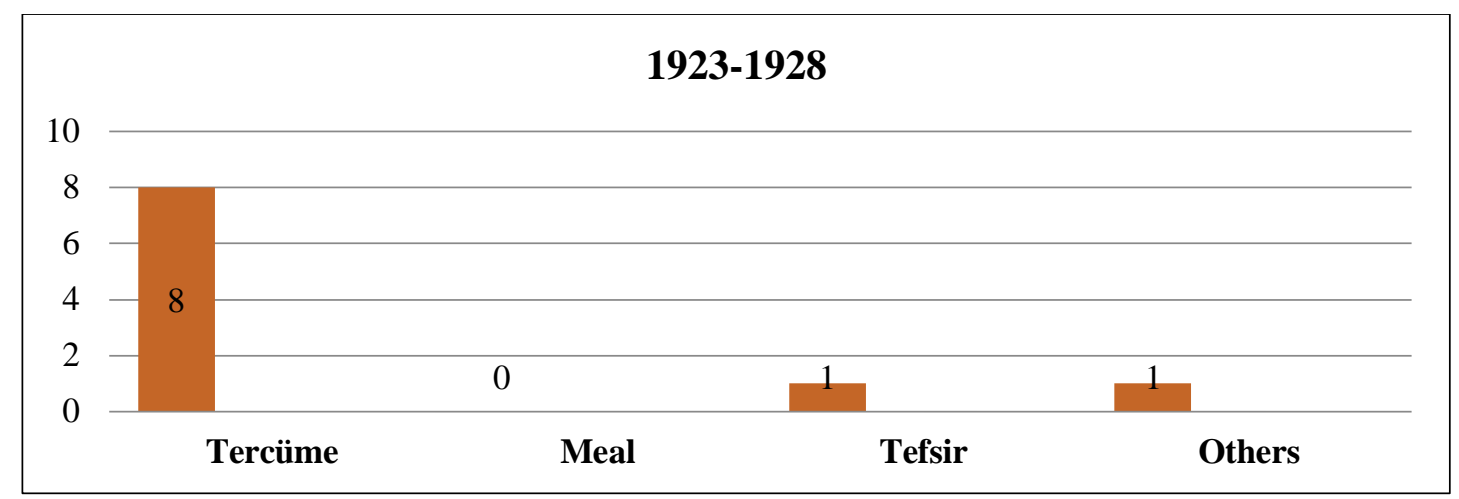

Figure 2 Qur'an retranslations in Turkish between 1923-19284

November 1928 was the beginning of the so called "Turkish Language Reform" in Turkey. The first phase of the reform was the adoption of the Latin alphabet over the Arabic script. The underlying motive of the reform was to achieve an extensive break from the Islamic past (Berk 9697). The reform was put into practice quite effectively and by the middle of 1929, all publications were using the new Latin alphabet. In terms of the translation of religious texts, the project was composed of different phases, including Türkşe Kur'an [Turkish Qur'an], Türkese Ezan [Turkish Call to Prayer], Türkse Tekbir [Turkish Takbir], and Türkse Hutbe [Turkish Hutbah] respectively, which caused great controversy and hot debates that continued to resonate in subsequent periods.

The first Qur'an translation printed in the Latin alphabet in Turkish was the transliteration of the Türkçe Kur'an-ı Kerim Tercümesi [Turkish Translation of the Qur'an] by İzmirli İsmail Hakk1 in 1932. The translation was first published in 1927 with the Arabic alphabet (Erşhahin 155). Ömer Riza Doğrul's translation Tanr Buyruğu- Kur'an-ı Kerim Tercüme ve Tefsiri [Command of the GodTranslation and the Exegesis of the Qur'an] was published in 1934 before the publication of the first volume of the state-commissioned translation by Elmallı Hamdi in 1935.

The transition to a new alphabet had considerable repercussions for Qur'an retranslations. The discussions on the translatability of the Qur'an were now guided by new approaches towards the potentials of the new alphabet. In this context, Ibrahim Hilmi made a radical attempt and published El-Mushafussserif [The Qur'an] in 1932. In this translation, he provided a transliteration of the Arabic original text in the Latin alphabet, as well as an interlingual Turkish translation. The translation was claimed to be prepared by a committee, but the identities of the committee members were kept secret. The translation faced harsh opposition. There were again rumors claiming the translator was a Christian Arab. This translation was further accused of distorting the Turkish alphabet and the meaning of the Qur'an (Erşahin 157). As a response to these accusations, İbrahim Hilmi sent a letter to Atatürk, President of the Turkish Republic at the time, explaining the motives behind his translation and defending it. However, official inspection by the Directorate of Religious Affairs concluded that the work was an attempt to adulterate the Turkish alphabet. Nonetheless, despite the disapproval of the authorities, this translation was accepted by the public

\footnotetext{
4 "Others" category refers to the Qur'an translations that do not include any of the terms " meal, tercüme, and tefsir" in their titles.
} 
and republished in 1936, 1937 and 1950 (Ocak Gez), demonstrating how the same translation might reverberate differently in different sections of a society.

Figure 3 demonstrates the number of Qur'an retranslations produced in the Republican era's second decade under different designations in Latin script as discussions on the project to Turkify the language of religion continued.

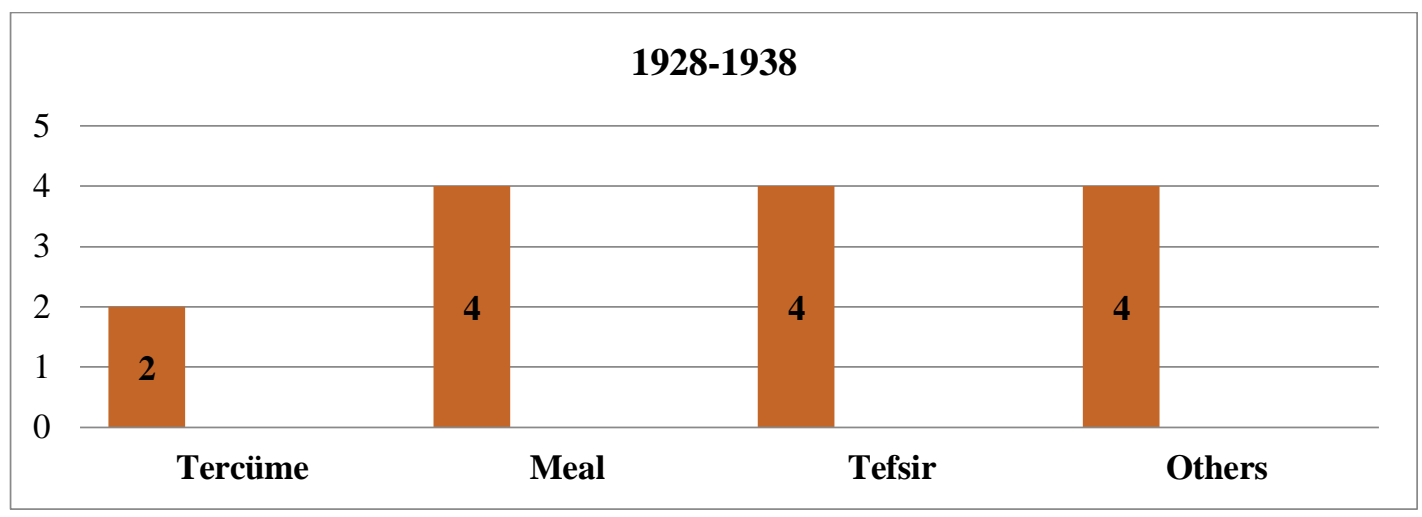

Figure 3 Qur'an retranslations in Turkish between 1928-1938

The division of this period in 1938 is deliberate because the completion of the translation by Elmallı Hamdi Yažr Hak Dini Kur'an Dili Yeni Mealli Türkese Tefsir [The Religion God, the Language of the Qur'an- New Exegesis with Synopsis of Meaning] in 1938 was a turning point in the history of Turkish translations of the Qur'an. The impact of this rendering on the Qur'an retranslations in Turkey derives from two facts. First, it was published with the strong support and approval of the state, which enabled a wide distribution network. Secondly, the translator Elmalılı Hamdi Yazır was a prominent Islamic intellectual of the period with a considerable influence in the field who proposed new conceptions and contextual frameworks. In the preface of this translation, Yazir precisely stated that the translation of the Qur'an could only be designated as meal and defined the term as follows: [... Meal means to diminish something. Thus, to express a statement with no full equivalence but with some deficiency is called meal. It is because of this deficiency, we used the term meal (Yazır 30). With the introduction of a new term (i.e. meal), Yazır challenged existing translations and deemed them inappropriate. Accordingly, he produced a verbatim translation in the Arabic syntax order and overtly stated that his translation was a humble human product which could by no means be equal to the sacred original. The motive behind this attempt lies in the sociopolitical conditions of the period. Yazır intentionally produced a complex and inversion-structured translation so as to make it inappropriate for any use in worship in the Turkification projects, which are briefly mentioned above. In this vein, his retranslation emerged as a site of discursive tension between an individual translator and the government, each side having different concerns over the same translation.

Governed by the socio-political premises of his period, Yazır's emphasis on deficiency has been decisive on the Qur'anic discourse in Turkey since then, and has frequently been used as a tool to justify new attempts for retranslations of the Qur'an. Different from his politically-oriented context, many translators instrumentalized "meal' as a sanction to prove the necessity of their 
translation (based on the assumption that any translation of the Qur'an is insufficient) and enjoyed the freedom of accepting the inherent insufficiency of their works before the sacred source text.

The following Figure 4 shows the number of Qur'an retranslations produced under the impact of the influential "meal" by Elmalil Hamdi Yazır as well as the rich texture of the designations used to define these translations.

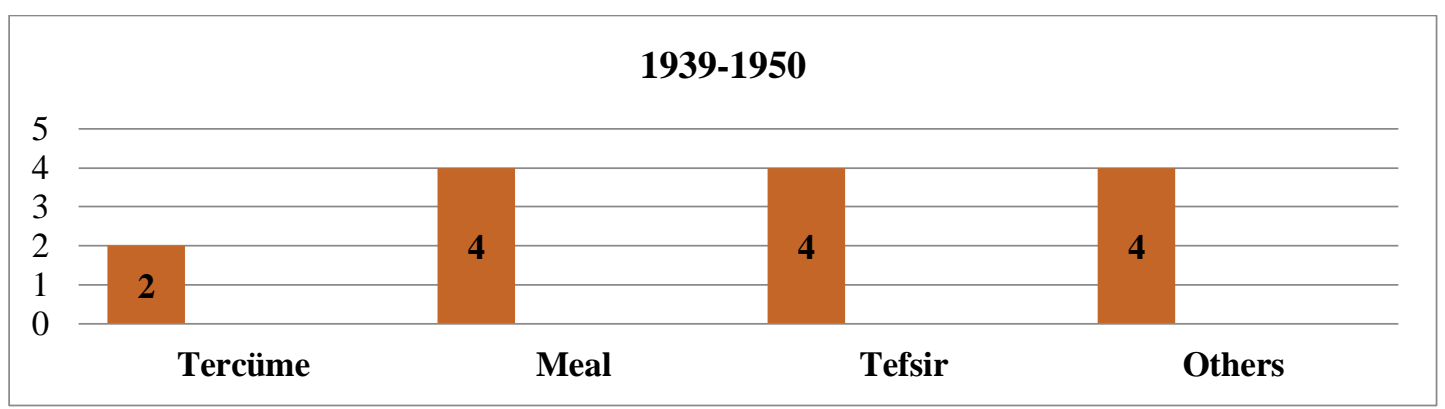

Figure 4 Qur'an retranslations in Turkish between 1939-1950

The periodization of Qur'an retranslations in Turkey chosen for the purposes of this study follows the socio-political changes the country has experienced. The end of the single party system in the late 1940s proceeded to a new phase with the victory of Demokrat Parti (DP) (Democrat Party) in the 1950 elections. The period between 1942-1947 was a time of non-translation for Qur'anic renderings. The challenge of DP (established in 1946) against the existing political paradigms by instrumentalizing religion as an asset of its political discourse had reverberations in the field of Qur'an translations as well, and new translations began to appear afterwards. Accordingly, the program to Turkify the call to prayer came to an end with an amendment in the legislation which legalized the recitation of the call in both Turkish and Arabic (Cündioğlu "Türkçe Kur'an"). In this period, the sale of religious publications gained considerable momentum. As an example, the Arabic original of the Qur'an, imported from Egypt, sold 250,000 copies in one year (Karpat 286).

During the period 1950-1960, several retranslations of the Qur'an were published under different headings (i.e. tercüme, tefsir, meal, etc). Among them were Kur'ân-ı Hakim ve Meâl-i Kerim [The Glorious Qur'an and Its Meaning] by Hasan Basri Çantay (1952) and Islam'nn Mukaddes Kitabı Kur'an-ı Kerim, Türkşe Tercüme ve Tefsir [The Holy Book of Islam: The Qur'an: Translation and Exegesis] by Hac1 Murat Sertoğlu (1955), which draw attention with their exhaustive use of the respective Qur'anic terms in their titles. In addition to these more conventional translations, some controversial titles appeared in the market such as the translation Kur'an [The Qur'an] by İsmail Hakkı Baltacıoğlu and Türkese Kur'an-ı Kerim [Qur'an in Turkish) by Osman Nebioğlu, which are both intriguing in that they did not bear any references to their translational nature. The emergence of these translations in the 1950s can be interpreted as a reflection of the changing conventions of the socio-political order, in which the rivalry between two leading political parties (Cumburiyetçi Halk Partisi [Republican People's Party] abbreviated as CHP and Demokrat Parti [Democrat Party] abbreviated as DP) both endeavoring to gain the majority in the parliament might have enabled Qur'an translators to act under freer circumstances under less official scrutiny. 
Figure 5 represents the increasing number of retranslations of the Qur'an in the 1950s, with the majority of the translations presented as tefsir (exegesis) in the titles among other renderings.

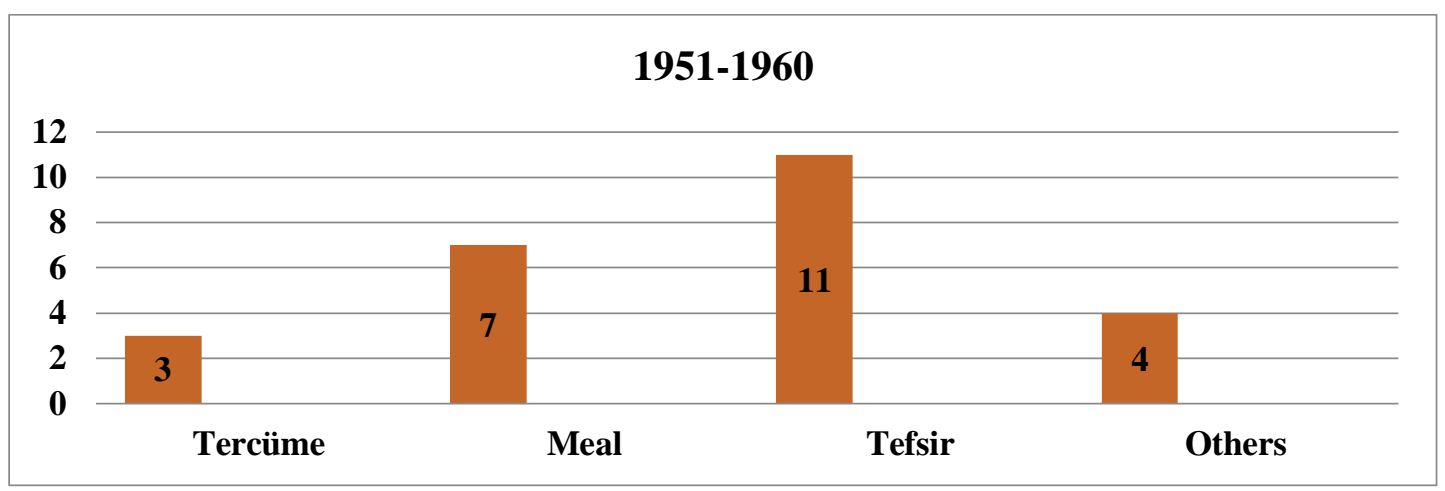

Figure 5 Qur'an retranslations in Turkish between 1951-1960

This period came to an end with the first coup d'etat in the Republican period on 27 May 1960. One of the first acts of the coup was to commission the translation of the Qur'an to the Directorate of Religious Affairs. Referring to Eric J. Zurcher and Ruşen Çakır, Berk defines this translation in relation to the attempts "to liberate the Islamic thought from the monopoly of those who knew Arabic and were the only ones to reach the sources and the establishment of Islam not just as a religion but also as a way of life" (183). During this time span, there were dozens of new Turkish retranslations of the Qur'an.

This era was also marked with Turkish translations of established exegeses of the Muslim world such as Hulasatu'l Beyan Fi Tefsiri' I Kur'an [The Explanation on the Exegesis of the Qur'an] (1966) and Fìzlali'l-Kur'ân: Kur'an'm Gölgesinde [Under the Shadow of the Qur'an] (1966) by Sayyid Qutb. These translations can well be contextualized in relation to the rising Islamist voice in the 1960s in Turkey. In this regard, it is a prevailing assumption that translation played a significant role in the revival of Turkish Islamism in the 1960s along with surrounding social, political, and cultural trajectories (Kara; Göle; Bora). Increasing interaction of the Islamist intellectuals with the foreign Muslim world prepared the grounds for new Islamic translations (Kazdal 275). In this context, the reverberations of the quest of Turkish Islamism to challenge its introvert nature and re-bond its broken ties with the ummah (Iş1k 412) appeared in the field of Qur'anic renderings with Turkish translations of contemporary exegeses of foreign Islamist figures.

Furthermore, this period witnessed the involvement of the press in the production of Turkish Qur'an translations. Several newspapers such as Milliyet, Akşam and Haber distributed Qur'an translations (mainly meal and tercüme) to their readers, which considerably increased the number of Qur'anic publications. As Figure 6 reveals, the quantity and the variety of Qur'an retranslations in Turkish continued to flourish in the 1960s. 


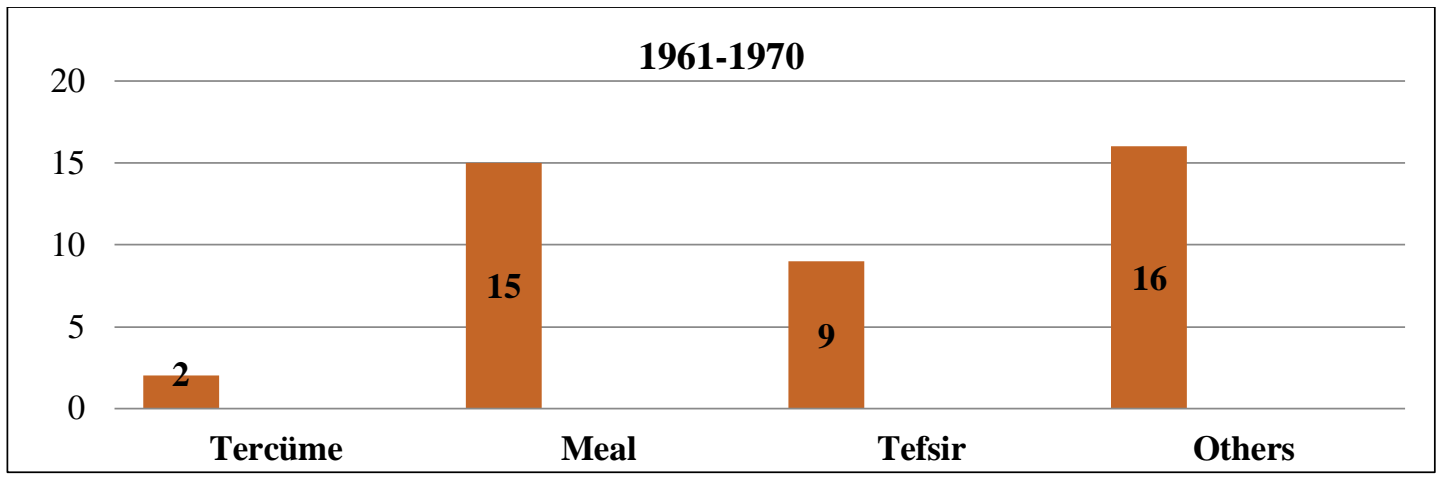

Figure 6 Qur'an retranslations in Turkish between 1961-1970.

The next decade also started with a coup attempt of the army on 12 March 1971. Between the years 1970-1980, several translations of the Qur'an were produced, largely predominated by the term "meal". There were no new renderings titled "tercüme" (translation) (apart from the reprints of the previous translations) published in this period, which might well have been a result of the conservative atmosphere the political crisis had created. In other words, socio-political anxiety might well have led to a conservative and conventional approach in the sphere of Qur'an translations and influenced the production of new retranslations under the designation of meal rather than tercüme (translation). As Figure 7 illustrates, meal outnumbered other translational designations during these years.

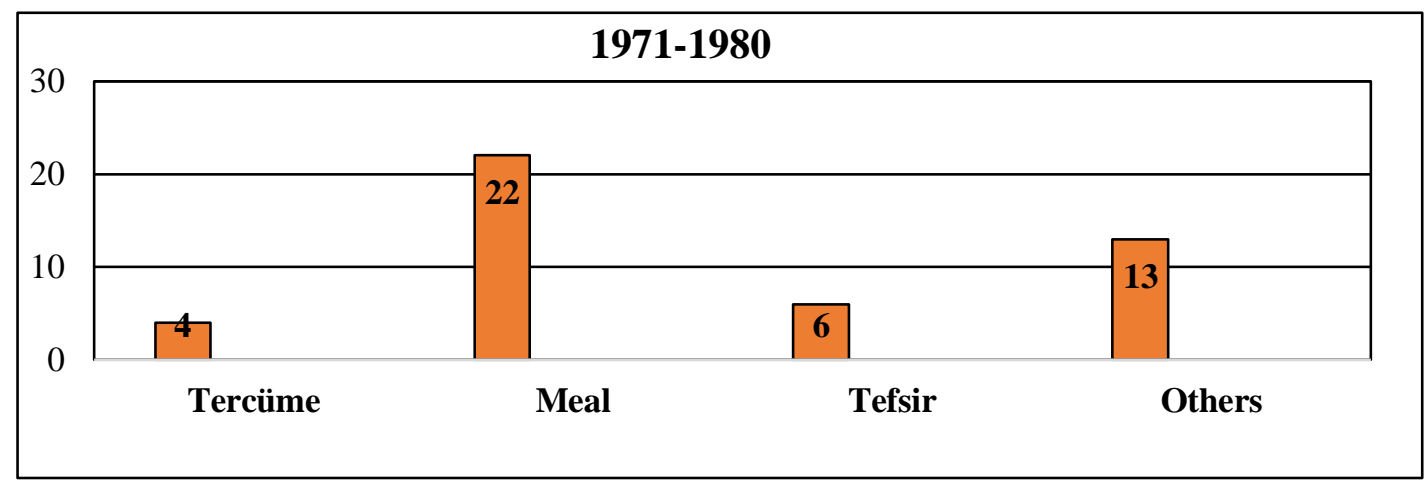

Figure 7 Qur'an retranslations in Turkish between 1971-1980

On 12 September 1980, the second coup d'etat was staged as a result of the political violence between far-right and far-left groups which was worsened by grave economic problems with high rates of unemployment (Zürcher 263). It radically transformed the economic, political, and cultural life in Turkey (Gürbilek). Turkish Qur'an translations are higher in number in that period compared to the previous decades. There was also an increase in the translations done from Arabic $(17 \%)$, which is defined as "an indicator of the growing Islamist currents as well as the inclusion of the religious education in primary and secondary schools; the building of new mosques; and the growing number of imam-batip (preacher) schools and Islamic bookshops" (Berk 182).

Moreover, repercussions of the waves of modernization in Turkey were also seen in the field of Qur'an retranslations. Different interpretations of the Qur'an were prepared based on 
modern discoveries and scientific inventions. Namely, some of the ayahs ${ }^{5}$,of the Qur'an were reinterpreted in relation to the new findings in the modern world. They were presented as interdisciplinary works between the theology and positive sciences. The exegesis Yüce Kur'an'ın Cağdas Tefsiri [The Contemporary Exegesis of the Glorious Qur'an] (1989) by Süleyman Ateş constitutes an example. The 1980s also hosted terminological diversity in the titles of the Qur'an translations. Rather than referring to them as tercïme [translation proper] or tefsir [exegesis proper], many new retranslations bearing complex titles such as "açıklamal meal' [explanatory synopsis of meaning], "mealen manzum açılama", etc. [explanatory synopsis of meaning in verse form] appeared in the market. Furthermore, it was in the 1980s when the concept ceviri (Turkish equivalent for the Arabic-origin word tercïme) first came to daylight in the world of Qur'an translations. In this period, two translations were published under this title: Kur'an-ı Kerim Meali: (Türkşe Cevirr) (1984) [The Meaning of the Qur'an- Turkish Translation] by Yaşar Nuri Öztürk; and Tanr Buyruğu Oku, Kur'an Nazım Ceviri [The Command of the God: Read- Turkish Verse Translation of the Qur'an] (1987) by Rıza Çiloğlu.

Figure 8 demonstrates the lack of any works titled tercüme, the prevalence of meal and other Qur'anic renderings with diverse-complex terminological designations given in the column "Others".

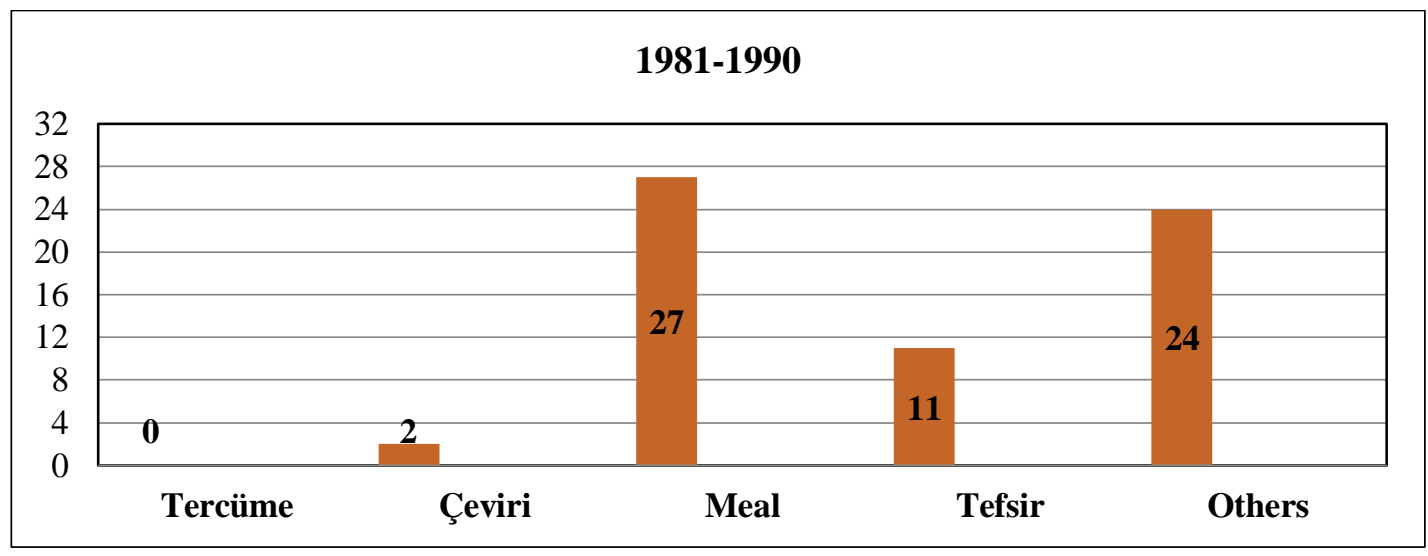

Figure 8 Qur'an retranslations in Turkish between 1981-1990

In the 1990s, the developments in the media (i.e. the launch of private TV and radiobroadcasting), and the emergence of new political platforms and ideological movements caused further diversification in the field of Turkish Qur'an retranslations. First, the number of translations of the Qur'an with no reference to their translational production began to increase such as Kur'an (1992) [The Qur'an] by Turan Dursun; En Mübim Mesaj Kur'an: Kur'an Hakkenda Yeni Mütaalaalar [The Most Important Message: the Qur'an- New Deliberations on the Qur'an] (1994) by Suat Yildırım. Secondly, female Qur'an translators appeared on the stage for the first time in the 1990s. The translation by Medine Balc1 was published under the title of Kur'an-ı Kerim ve Kelime Meali [The Qur'an and its Literal Meaning] in 1991. Thirdly, the diversity in the designation

\footnotetext{
5 Ayah is the Arabic word referring to the verses of the Qur'an. They are of varying lengths and make up the chapters (surah) in the Qur'an.
} 
of translations gained further complexity. The heading of the following Qur'an translation vividly manifests the altering translational premises of the period: Kur'an'ı Anlamak: Tercümeden Meale Mealden Mini Yoruma [Understanding the Qur'an- from Translation to Meaning, from Meaning to Mini Interpretation] (1996). Figure 9 portrays the increasing number of the Qur'an retranslations and the momentum for the complex titles over the so-called translation proper.

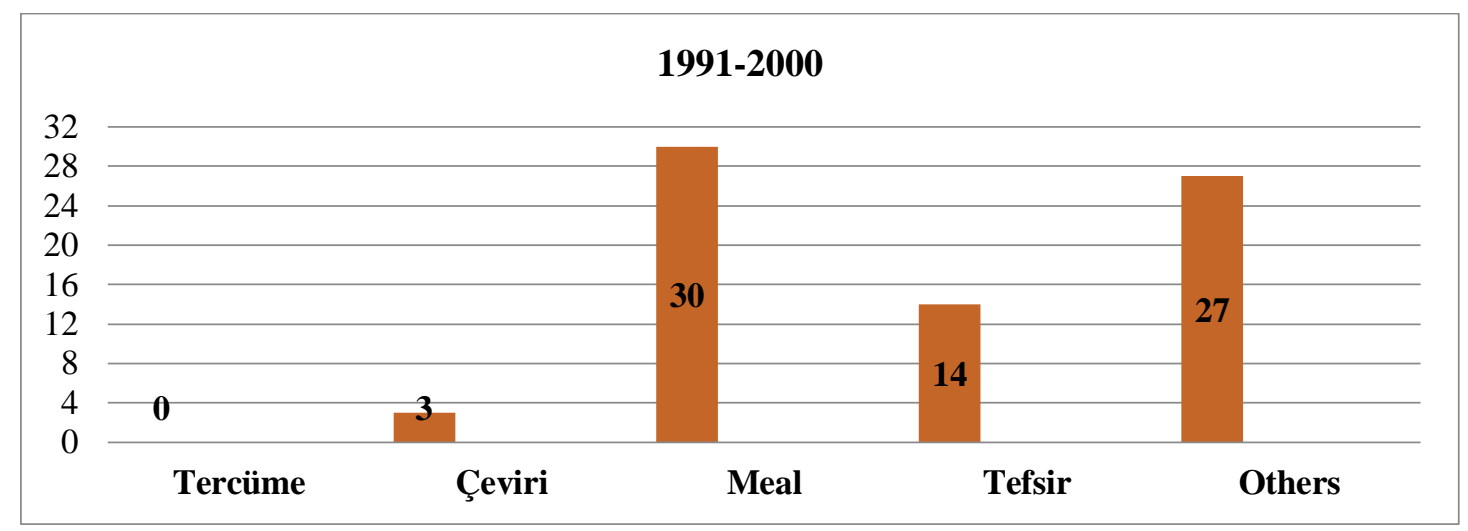

Figure 9 Qur'an retranslations in Turkish between 1991-2000

The new millennium can well be called the "the age of meal", considering the remarkable boost in the number of Qur'anic renderings called "meal'. Among the motives behind this increase, the rise of a right-wing political party (i.e. AKP) with a focus on disseminating the Islamic discourse, the developments in the publishing sector, wide access to internet, and the increasing interest in religious publications in the public can be named. Above all, I think through time, the term meal gained such an established position in the world of Qur'an translations that it emerged as the most convenient and representative way of presenting a retranslation of the Qur'an in Turkish. Tracing two Turkish words interchangeably used to refer to translation tercüme and çeviri in the titles of Qur'an translations, it would not be wrong to say that çeviri has gained popularity and has an overwhelming success over the term "tercüme", doubling it in number.

What is more, compositional changes in Qur'an translations were also observed in this period. Qur'anic renderings composed according to the chronological order of the revelation of the ayahs or themes of the surahs were produced. These cases might be regarded as products of a parallel argument to the "retranslation hypothesis" with their innovative nature bringing novelties to the existing repertoire.

This decade hosted a female Qur'an translator as well. Necla Yasdıman translated the Qur'an into Turkish in 2006, becoming the second female Qur'an translator in Turkish. Her translation called Kur'ân Tablili: Arap̧̧a Gramer Ișuğmda Sözlük-Meal-Tefsir [The Analysis of the Qur'an: A Dictionary, Meaning and Exegesis of the Qur'an in the Light of Arabic Grammar)] was additionally designed as a grammar book for learners of Arabic. 
Moreover, as a crucial indicator of the correlation between the socio-political context and Qur'an translations, the Alevi Kur'an Tefsiri (2012) [Alawite Qur'an Exegesis] by Ahmet Bedir was published following the attempts for a better recognition of Alevi community ${ }^{6}$, constituting an ultimate example to the praxis of retranslations of the Qur'an in Turkey. Figure 10 shows the striking number of meal works, with a boost in their numbers observed in all areas of Qur'anic renderings.

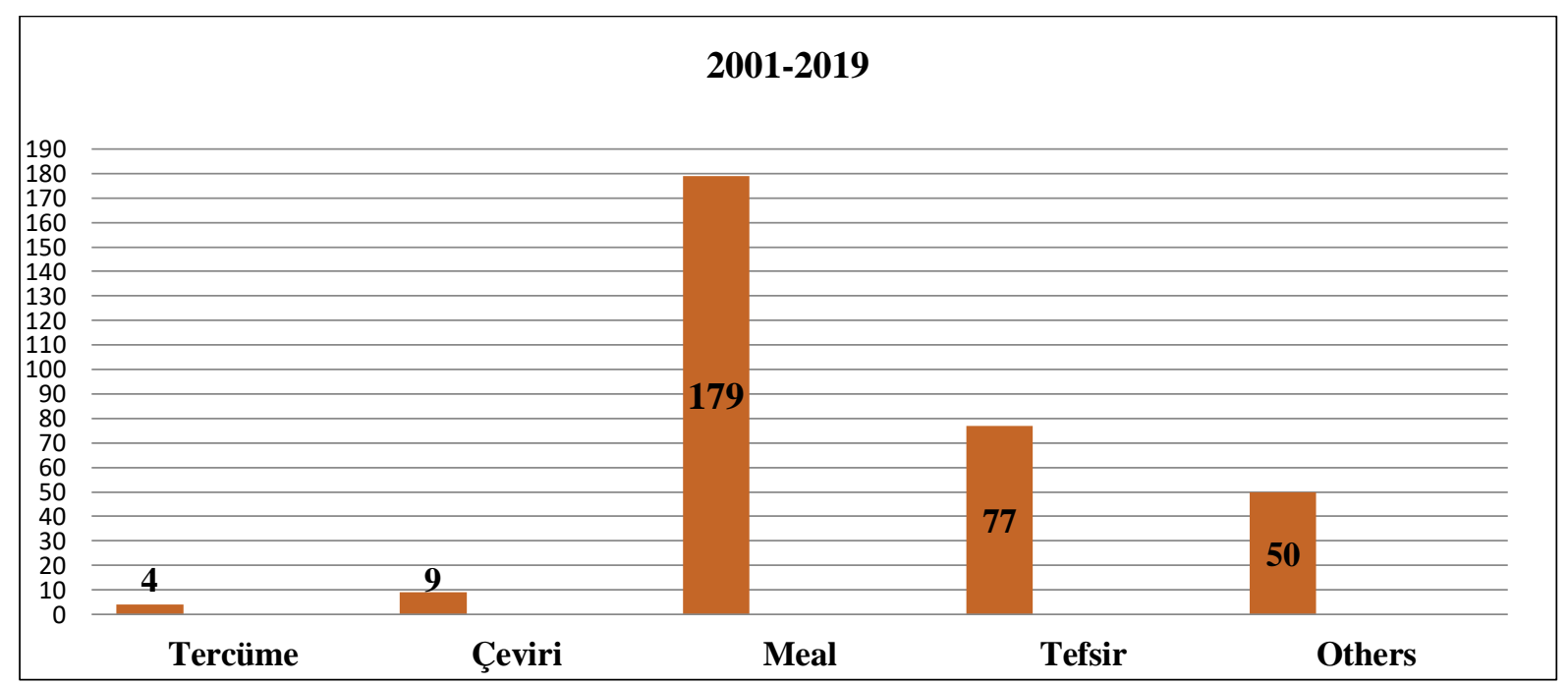

Figure 10 Qur'an retranslations in Turkish between 2001-2019

\subsection{A Critical Overview of the Discourse on Qur'an Retranslations in Turkish}

This section concentrates on distinctive premises of the decades-long translational journey of Qur'an retranslations in Turkey. The corpus of the study is composed of exemplary prefaces written by Qur'an translators of respective temporal spans under scrutiny. Their varying foci reveal different approaches of the agents towards the retranslation of the Qur'an. The ways in which they explain and justify the need for their respective translations illustrate the rich and complex fabric of Qur'an retranslations in Turkey.

To begin with the first translators of the Qur'an in the early Republican period, İzmirli İsmail Hakkı expresses the motives behind his translation titled as Kur'an-ı Kerim ve Türkçe Anlamı- Ma'ani$i$ Kur'an (1927) [The Meaning of the Qur'an- Turkish Translation of the Qur'an] with a concentration on the use of plain language, fidelity and understandability, which would be echoed frequently in the following Turkish retranslations of the Qur'an:

[I tried to explain the meaning of the original as similarly as possible with a proper translation in accordance with the rhetoric our language. With respect to language, I may claim no success and the style may have gotten a bit loose, but I guess translation does not include circumlocution. I did not translate before understanding the ayah, I did not insert any words

${ }^{6}$ The Alawite is a term used to refer to heterodox Muslim Shi'a community in Turkey. They constitute the largest religious minority who differ considerably from the Sunni Muslim majority in their practice and interpretation of Islam in Turkey. 
that did not reflect the meaning of the original. The words of God are not presented in an incomprehensible way.] $]^{7}$ (Izmirli)

As one of the most established Qur'an translators in Turkish, Elmall1 Hamdi Yazır presents an authoritative translator portrait setting criteria for a proper Qur'an translation and translator. Yazır (1935) claims that a Qur'an translator should be able to read the Qur'an lacking vowel markings as a sign of competence in Arabic language. He complains about the Qur'an translators of the time and argues that the translators could not read even the Qur'an with vowel markings and they pretend to come up with meaning of the Arabic Qur'an (Wilson 202). As a proponent of the view that the Qur'an cannot be truly translated, Yazır explicitly states in the preface of his translation that it was not his own choice but he was commissioned to translate the Qur'an by the state with references to the articles of his contract (19). Following these statements, Yazır (1935) argues that the Qur'an cannot be translated and what he does is to write an exegesis and produce a meal via strictly preserving the syntax structure of the source text. In this regard, Yazır defines tercüme as follows:

[Translation is to express the meaning of a word in another language with a corresponding expression. It must be equivalent to the original in clarity and signification, in summary and in detail, in general and in particular, in strength and in accuracy, in eloquence of style, in manner of elucidation, in the production of knowledge and in craft. Otherwise, it would not be a complete translation (translation proper), but a deficient version.] (9)

With his definition of an utmost ideal translation, Yazır implicitly puts forth the impossibility of translating the Qur'an. Yazır states that previous translations and contemporary discussions on the forthcoming translations create an illusion of reflecting the reality of the Qur'an:

[Under these conditions, people claiming to translate or to have translated the Qur'an would be just lying. [...] There are even some who do not understand the Qur'an and do not read exegeses with the claim that it includes the interpretation of the exegesis writer, and by reading just the translations of the Qur'an, they claim to analyze the Qur'an. [...] There are also others, who are not content with saying the translation of the Qur'an and dare to say “Turkish Qur'an”. Is there such a thing as Turkish Qur'an, you fool?] (15)

Under these premises, Yazir introduces the term meal as a suitable term for designating Qur'an translations, which is briefly defined as translating with some deficiency and without a claim to represent and replace the original. From a "retranslation hypothesis" perspective, I can argue that this translation was not produced to fill a gap or improve previous translations. It was produced to construct a metanarrative over Qur'an translations (emphasizing their insufficiency vis-à-vis the sacred original) to challenge the attempts to Turkify the language of religion, which was high on the agenda in the late 1930s in Turkey.

${ }^{7}$ All translations provided in square brackets are mine, unless stated otherwise. 
The translation produced by Yazır (which I propose calling a "canonical translation") constitutes a myriad for Qur'an retranslations in Turkish. As a state-sponsored translation by a prominent Islamic agent, it opened the path for other translations and received widespread circulation with a wide distribution line. In other words, this retranslation with no claim to bring newness to the existing repertoire triggered other retranslations of the Qur'an by establishing the premises of a Qur'an translation in the eye of the readership in the early 1940s.

The following decade was marked with radical attempts in the titles of Qur'an translations. The translations called Türkşe Kuran [Qur'an in Turkish] (1957) by Osman Nebioğlu and Kur'an [Qur'an] (1959) by an anonymous translator ignited discussions on the presentation of Qur'an translations. Abdülbaki Gölpinarlı (1955) draws attention to this issue in the preface to his translation as follows: “... sunduğumuz kitap Türkese Kur'an değgl, Kur'an'in Türkese’ye tercümesidir [This book is not a Turkish Qur'an but a Turkish translation of the Qur'an]” (XXXVI). This sensitivity can well be interpreted as a resonance of the prolonged debates in the political agenda on the conduction and annihilation of the practice of Turkish call to prayer (i.e. eqan].

In the 1960s (hosting the resurgence of Turkish Islamism), Islamic publications (particularly translations) began to boom in Turkey, which also resonated in the world of Qur'an translations. In this context, the abundance of retranslations of the Qur'an was subject to criticisms. Mehmed Şevket Eygi (1961) criticizes the excessive number of Qur'anic renderings and accuses their publishers of using the Qur'an for financial profit. This case shows us how the concerns and interests of the market can serve as a guiding principle in the context of retranslations even in the case of a holy book:

[The popularity of Qur'an translations starting after the Second Constitution is a harmful trend. Before the Second Constitution, the Ottoman state used to keep the press under control and did not let publishing of arbitrary, erroneous Qur'an translations and exegeses. [...] They cannot deceive us. All of these translations are for economic gain and interests.] (Eygi 5)

This decade also witnessed the emergence of intralingual translations of Yazır's canonical Qur'an translation. These editions published under the title "sadelestirme" [simplification] echo well the premises of the "retranslation hypothesis" with their claim on the ageing of language:

[In the recent years, there occurred a need for different editions of Elmalll's work in the form of meal, by either simplification or by preserving the original translation and explaining the old word either in parentheses or in footnotes.] (Karsl1 66)

In this regard, archaic words used in the translation by Yazır were mostly changed to (modern) Turkish words, and the syntactic order was regulated according to the Turkish language. Besides, these (intralingual) retranslations merit attention with their intervention in the composition of Yazır's translation. His original translation is composed of a meal and ten volumes of exegesis. However, the edition published in 1962 does not include the exegesis but the simplified version 
of the meal section solely. In this regard, "retranslation" emerges as the site which breaks the unity of a former translation. Despite the committee's claim to make this translation more accessible and easier to understand for a Turkish readership, I think the publication of this shortened version also originated from financial concerns considering the wider share of translations (and meals) in the market compared to exegeses.

The discourse on the Qur'an retranslations in the 1970s concentrates on the terms used in the titles of Qur'an translations with an observable increase in the preference for " meal' over "tercüme". In this context of production, well-known Islamic scholar Süleyman Ateş (1977) elucidates on the term "meal" and emphasizes the inherent and inevitable deficiency of any Qur'anic rendering in Turkish. In this sense, the production of a new translation with an initial acceptance of its deficiency can be interpreted as a premise that nullifies the claim of the "retranslation hypothesis", which is based upon the idea of progress and betterment of the translation:

[Translation is transferring a statement from one language into another [.....] Verbatim translation is what replaces the original. No translation can replace the original Qur'an. No translation can reflect all the miraculous features of the Qur'an. Because Qur'an is the word of God/ revelation... Nevertheless, Qur'an translations are called meal rather than tercüme, as translation is what replaces the original. Meal is to transfer the original into another language with some deficiency. It is regarded as appropriate to call Qur'an renderings meal to state that the translation has no claim to replace the original but is a representation with some deficiency.] (Ateş IX)

The 1980s maintain the concerns over the terms used to designate Qur'an translations. This period also marks the debut of the particular Qur'anic and translational attribution to the word "meal' as an entry in Turkish dictionaries (see Büyük Türkse Sözlük [Grand Turkish Dictionary] (1982)), which can well be regarded as evidence of its terminological establishment. The definition is further detailed with the word's derivative forms. As an example, the word “mealci" $[$ meal $+c i]$ is defined as "Kur'an-ı Kerim meali hazırlayan kimse, Kur'an-ı Kerim meali okuyan kimse [The person who prepares the meal of the Qur'an, the person who reads the meal of the Qur'an]", where dual agency is attributed. The use of the same designation both for the producer and the addressee of the translational act can seem confusing at first sight. It is a consequence of a particular discussion concerning Qur'an translations since the 1980s. This decade witnessed the debut of meal-oriented arguments in Turkey. It bore a slightly pejorative connotation. In these years, an increasing amount of Qur'an translations published in several forms as "meal" entered wide-spread circulation (Hamidullah and Yaşaroğlu 1993) and began to receive considerable criticism with the claim that they violated the framing features of "meal' with radical shifts in forms, rank-bounds and interpretations of certain ayahs. Some of these translations were even accused of manipulating the essence of the Holy book. This criticized dependence on the "meal' (i.e. Turkish rendering of the Qur'an) rather than the original Qur'an in Arabic also gave birth to an ideological orientation of its own right. It was called "mealcilik". The word is defined as "Kur'an-ı Kerim meali okumayn ön plana alma görüşï" [The view, prioritizing reading the meal of the Qur'an]. This view over-prioritized the 
meaning of the Qur'an which put Qur'an translations at the core of the world of belief and put Sunnah and hadith (i.e. practices and expressions of the Prophet Mohammad) into a relatively secondary and/or insignificant status. These arguments have placed "meal" at the centre of discussions on Qur'an translations with unanswered questions on the potentials of the translation vis-à-vis the canonical religious original since then.

Moreover, this period hosted discussions on the potentials of different translation strategies for Qur'an retranslations. In this regard, translators' motives to explain the grounds for their introduction of a new translation into the existing Qur'anic repertoire began to illustrate a shift in the discourse on translations of the Qur'an. The concentration on diversity and innovation began to be voiced more loudly in this period compared to preceding decades. In their translation, Atay and Kutluay (1981) confirmed that the sense for sense translation technique, which they applied, was the best way to translate the Qur'an to justify their retranslation rather than mimicking former retranslations within the plethora of Qur'an translations in Turkish:

[... Thus, the most appropriate way is to express in Turkish what is understood from the Arabic original rather than producing a word-for-word translation. We followed this method in our work.] (Atay and Kutluay IX)

In the meantime, the 1990s is marked with the discussions on the integration of the Muslim individual into the secular public sphere and the resurgence of “Kur'an'a Dönüs Hareketi" [Returning to the Qur'an], prioritizing to understand the premises of the Qur'an to reconstruct religious life as a reaction to so called radical Islamist views. In this period, Yaşar Nuri Öztürk emerged as a symbolic and controversial figure who was influential in the debates of the period. Öztürk (1994) emphasizes the importance of using plain language in translation to make it accessible to all the individuals (13), which he expresses as follows in the preface of his translation: "Our main aim in reading a meal is to understand the words of God without including the interpretation of a human" (Öztürk 10).

The focus on the socio-political and cultural structures in the production of Qur'an translations also resonates in the preface of another Qur'an retranslation of this decade. Mustafa Hizmetli (1998) concentrates on the temporality of the translations and accordingly claims that each era requires a new translation of the Qur'an to address the current issues of the period. In this vein, elaboration on the source text (i.e. the Qur'an) as an open book, which enables different interpretations in different time periods, emerges as a radical and controversial approach among the conventional views on the Qur'an. Even though this approach (viewing Qur'an as an open book) is harshly challenged by many established Islamic scholars, it continued to serve as a guiding principle for many other retranslations of the Qur'an, especially in the early 2000s:

[The message of the Qur'an is universal and beyond the eras. Thus, it addresses all ages and its semantic feature is to be re-analyzed in each society. It is not possible to translate it with all its artistic and semantic richness. In this situation, the translator cannot do anything other than transferring what s/he could understand from the text. Anyway, each translation 
inevitably limits the structure of the act with temporal and social accumulation of the society it is to be produced in.] (Hizmetli 8)

The discourse on the Qur'an retranslations in the new millennium can best be defined with the word "diversity". Challenging conventional prose translations of the Qur'an, new retranslations in the form of verse appeared in the market in this period. As an example, Nusret Çam (2002) called his translation Şïr Diliyle Kur'an-ı Kerim Meali (2002) [The Meaning of the Qur'an in Poetic Language] and posited that the eloquence of the Qur'an embodies a high form of literature and it could only be rendered as a poetic work. Whereas, Edip Yüksel (2000) produced a Qur'an translation titled as Mesaj: Kur'ân Cevirisi (2000) [Message: Qur'an Translation] in which he excluded prophetic references. He argued that conventional Islamic scholars misguided the public with ungrounded claims on Islam and loaded it with superstitions. With his translation, Yüksel (2000) claimed to provide the readership with the clear message of the Qur'an produced under the light of modern sciences.

The freedom enjoyed among the Qur'an translators of the period also had reverberations in the compositions of the retranslations. New translations began to be produced with different chronological orderings or thematic concentrations than the source text. The translations Ayetlerin Inis Sirasina Göre Kuran Cevirisi [The Translation of the Qur'an in the Order of the Revelation of the Ayahs] (2006) by Abdurrahman Abdullahoğlu; and Konularna Göre Kur'an Cevirisi [The Qur'an Translation Classified According to the Subjects] (2008) by Ömer Dumlu can be counted as examples of these cases respectively.

Moreover, the concerns on the reception of the Qur'an translations are noteworthy in this decade. Translators positioned their retranslations with an emphasis on their interpretative nature and inherently stressed their very existence in the production of these translations. This new approach differs greatly from the humble and passive translator profile primarily constructed in the context of "meal" by Yazır (1935), demonstrating how governing premises of discourse on Qur'an translations have been subject to change. In this regard, İhsan Eliaçık (2007) criticizes the misleading usage of meal to create an illusion before the eyes of the readership as follows:

[Meal is hearing what is not told in the text [...] Qur'an is not just a written text. Thus, its meal is not the act of writing the overt meaning next to the source text. On the contrary, it is the act of hearing what is not told in the source text... I think the term meal is not used correctly in Turkish. Most of the titles of Qur'an translations in Turkey are as Kur'an-1 Kerim ve Yüce Meali, which means Qur'an and my glorious commentary... Every meal is an interpretation. Claims stating "I translate without including my commentary" are the manipulation of the reader unless a specific aim is made explicit.] (Eliaçık 6-10)

Last but not least, only one among the prefaces of a number of Qur'an retranslations made explicit references to translation theories. Salih Akdemir (2004) expresses that Qur'anic renderings in Turkey are devoid of sound and consistent translation strategies. Despite the blurry framing of his postulate, expressions of Akdemir in Son Çağr Kur'an (2004) [Last Call-Qur'an] referring to 
functionalist theories of translation merit attention as an attempt to justify a Qur'an retranslation on the basis of conceptualizations in translation studies.

[A successful Qur'an translation can only be produced by heeding that the source text is originally an oral text, by analyzing the historical background to explicate the inexplicit expressions, by determining the events as if living thorough them and by reconstructing the text if required. Anyway, it should not be neglected that any translation is an interpretation. [....] A functionalist translation theory based on Critical-Philosophical Hermeneutics is the best method to produce a Qur'an translation, which the public has been looking forward to for a long time. In this translation, we tried to apply this method.] (Akdemir XXV)

Then comes the question: "what triggered this diversity in the world of Qur'an translations in Turkey in the early $21^{\text {st }}$ century?" The answer sits within the triad of political, social, and cultural premises. First, it is possible that the triumph of a political party (AKP) with an overt Islamic inclination in 2002 might have had a boosting affect in the sphere of religious publications. With a government instrumentalizing religion as a crucial asset of its discourse, Islamic concerns began to be uttered more loudly in the society, which simultaneously increased the interest in religion. Besides, the integration of religion into the social order resonated through the increasing visibility of religious sects (i.e. cemaat), each of which claimed to produce a particular Qur'an translation for their followers. In this regard, it can well be argued that retranslations of the Qur'an served as areas of tension among emerging religious groups in Turkey in the 2000s. As well as these socio-political motives, publishing opportunities in the press and the diversification of the addressees probably had an impact on the increasing number of retranslations of the Qur'an in Turkey.

\section{Conclusion}

In this study, I revisited the recurring question of "why certain texts are repeatedly translated while others are translated only once?" within the context of Qur'an translations. I aimed at exploring the discourse on the particular features of numerous retranslations of the Qur'an in Turkish by replacing the literary concentration of the retranslation paradigm with production practices of religious texts.

Glancing through the giant corpus of Qur'an retranslations in Turkish, I focused on their paratextual elements (i.e. titles on the book covers, and prefaces) and conducted both quantitative and qualitative analyses. The numeric analysis has revealed that the production of the Qur'anic retranslations portrayed a continuum with no considerable intervals in decades. There has also been a steady increase in the number of productions, referring to the fresh and continuing interest in this canonical religious book. In this vein, I attempted to analyze the production cycle of these retranslations with references to the temporal and spatial contexts of the periods. By depicting social, political, economic, and cultural conditions of the decades under study, I suggested that they might have been decisive on the quantity of the retranslations of the Qur'an in Turkey along with other translation-oriented conditions. 
Moreover, the chronological overview of these retranslations has demonstrated that it was not only the numbers of translations that changed over the years but also that the designations/titles of these renderings have diversified. In this context, different terms have been used to name Qur'anic renderings, each bringing forth its very own discourse on translation as a way of justifying the necessity of the relevant retranslation.

In the second stage of the analysis, I provided an overview of the discourse governing Qur'an retranslations in decades with several references to statements by Qur'an translators. Each period proved to be regulated by different and overlapping concerns, which I attempted to associate with the social, political, and cultural circumstances of respective temporal frameworks. In this regard, the 1950s emerged as a relatively free translational context for Qur'anic renderings under the shadow of political rivalry that instrumentalized religion. The 1960 s seemed to have been considerably affected by the translation-oriented resurgence of the Islamist discourse in Turkey. While the 1980s were marked with "meal' discussions leading to an ideological metadiscourse called "mealcilik," which prioritized reading translations of the Qur'an vis-à-vis supplementary religious sources. Whereas, the hybridity and abundance of the new retranslations of the Qur'an in the new millennium (i.e. the 2000s) mainly derived from the new neo-Islamic government, the integration of religious life into the public sphere, the developments in the press, and/or the enhancement of channels of information for religious concerns.

Translators' motives for positioning their retranslations within the Qur'anic repertoire in Turkey were disguised under various statements. The meta-narrative constructed on Qur'an retranslations manifests itself in the prefaces of the respective translations. Some translators/preface-writers concentrated on the term meal as a way of acknowledging the intrinsic deficiency of the human translator to translate the words of the Holy Creator. By defining this term as "a personal interpretation of the Qur'an" the translators seem to have opened up a space for their own translations and offer a way for further welcoming new Qur'anic translations. Some others emphasized their novel approach to translation with respect to methods and compositional strategies to justify their retranslations. In this vein, it is possible to come up with a continuum of examples with supporters of slavish adherence to the original vis-a-vis proponents of creative compositions producing Qur'an translations in verse form on each pole.

Furthermore, the prior concentration on acceptability in translation seems to have been replaced with understandability. This discourse prioritized meaning over other concerns and is presented as the underlying ground for retranslations of the Qur'an. This view brought forth changes in the order of the surahs in accordance with their date of revelation as well as retranslations produced/interpreted according to the findings of positive sciences. Also, I argue that the discourse on Qur'an retranslations has been shaped by its own dynamics as well as social, political, and cultural premises. The abundance of already available renderings of the Qur'an led translators to seek alternatives in their production to justify the necessity of their translations. Besides, I also think that the presence of high numbers of Qur'an retranslations on the market created the illusion of a great demand for retranslations of the Qur'an, which, in turn, encouraged 
publishers to produce new ones. On this point, probably no one was wrong as new renderings of the Qur'an continue to appear in the market to be sold every day.

As a concluding remark on the discourse on Qur'an translations in Turkey, I argue that the claim on "newness" has been the prevailing premise underlying new Qur'anic retranslations in Turkey. The translators did not seem to show interest in "improving" former retranslations. In other words, they were not concerned with the betterment of preceding translations and mostly evaluated their translations in isolation from others. Considering the initial admission of producing a deficient translation in the context of "meal", it is an expectable outcome that translators of the Qur'an did not aspire for progress and/or perfection in their new retranslations. In this regard, the main justification mechanism has been constituted on the "newness" each retranslation offered to the repertoire in line with the framing socio-political narrative. In fact, this is not too far detached from the retranslation hypothesis with its emphasis on the "lack and deficiency" in the repertoire. All factors considered, the world of retranslations of the Qur'an will most likely remain a controversial and simultaneously productive site for translators and translation scholars in the future, constituting a full-fledged area of Translation Studies. 


\section{REFERENCES:}

Abdullahoğlu, Abdurrahman. Ayetlerin İniş Sirasına Göre Kuran Cevirisi. Ozan Yayınc1lı, 2006.

Akdemir, Salih. Cumburiyet Dönemi Kur'an Tercümeleri: Eleștirel Bir Yaklașım. Akid Yayıncılık, 1989.

Akdemir, Salih. Son Căgr Kur'an. Ankara Okulu, 2004.

Atay, Hüseyin, and Yaşar Kutluay. Kur'an-ı Kerim ve Türkşe Anlamı (Meal). Diyanet İşleri Başkanlığ1 Yayınlar1, 1981.

Ateş, Süleyman. Kur'an-ı Kerim ve Yüce Meali. K1lıç Kitabevi, 1977.

Aydar, Hidayet. Kur'an-ı Kerim'in Tercümesi Meselesi. Kur'an Okulu Yayınc1l1k, 1996.

Berk, Özlem. Translation and Westernization in Turkey - From the 1840s to the 1980s. Ege Yayinlar1, 2004.

Berman, Antoine. La retraduction comme espace de traduction. Palimpsestes, 13, 1990, pp. 1-7.

Binark, İsmet and Halit Eren. World Bibliography of Translations of the Meanings of the Holy Qur'an, Printed Translations (1515-1980). Research Center for Islamic History, Art, Culture (IRCICA), 1986.

Bora, Tanıl. Cereyanlar-Türkiye'de siyasi ideolojiler. İletişim Yayınları, 2017.

Chesterman, Andrew. "A Causal Model for Translation Studies". Intercultural Faultines. Research Models in Translation Studies I : Textual and Cognitive Aspects, edited by Maeve Olohan, St. Jerome, 2000, pp. 15-27.

Collombat, Isabelle. "Le XXIe siècle: l'âge de la retraduction." Translation Studies in the New Millennium, vol. 2., 2004, pp. 1-15.

Cündioğlu, Dücane. Türkege Kur'an ve Cumburiyet İdeolojisi. Kitabevi, 1998.

Cündioğlu, Dücane. Kur'an Cevirilerinin Dünyası. Kapı Yayınları, 2011.

Çam, Nusret. Şiir Diliyle Kur'an-I Kerim Meali. Se-Ba Ofset, 2002.

Dumlu, Ömer. Konularna Göre Kur'an Cevirisi. Ozan Yayıncıllk. 2008.

Durmuş, Zulfikar. Kur'ân'ın Türkşe Tercümeleri: 'Azৃiz Kur'an' ve İnsanlĭga Son Căğrn' Örneği. Rağbet Yayınlar1, 2007.

Eliaçık, İhsan. Yaşayan Kur'an- Türkşe Meal. İnşa Yayınları, 2007.

Ergin, Osman. Türk Maarif Taribi. Eser Neşriyat, 1977

Erşahin, İsmail. "Cumhuriyetin İlk Yıllarında Kur'an Meali Yayıncilığı: İbrahim Hilmi Örneği." Toplum Bilimleri, vol. 5, no. 9, 2011, pp. 149-160

Eygi, M. Şevket. “Kur`an-1 Kerim in Tercümesi Meselesi.” Hilâl no. 16, 1961, pp. 4-5.

Genette, Gérard. Paratexts: Thresholds of Interpretation. (Jane E. Lewin, Trans.) Cambridge University Press, 1997.

Göle, Nilüfer. "Secularism and Islamism in Turkey: The making of elites and counter-elites". The Middle East Journal, 51 (1), 1997, pp. 46-58.

Gölpınarlı, Abdübâki. Kur'an-ı Kerim ve Meali. Remzi Kitabevi, 1958.

Gürbilek, Nurdan. Vitrinde Yasamak: 1980'lerin Kültürel İklimi. Metis, 2009.

Hamıdullah, Muhammed. Kur'an-ı Kerim Taribi ve Tükese Tercümeler Bibliyografyası. Yağmur Yayınevi, 1965.

and Macit Yaşaroğlu. Kur'an Taribi / Kur'an-ı Kerim’in Türkçe Tercüme ve Tefsirleri Bibliyografyası. IFAV Yayınları, 1993.

Hizmetli, Mustafa. Kur'ân-ı Kerim’in Türkçe Anlamı. Birleşik Yayınları, 1998. 
Işık, Vahdettin. “Türkiye'deki değişimi İslamc1 dergiler üzerinden okumak”. Toplumsal değişim sempozyиmи Istanbul Medeniyet Hareketi, 2016, pp. 411-444

İzmirli, İsmail Hakkı. Kur'an-ı Kerim ve Türkçe Anlamı (Ma'âni-i Kur'an).Eren Yayınları, 1977.

Kara, İsmail. İslâmcularn siyasi görüsleri. Dergâh Yayınları, 2001.

Karpat, Kemal H. Turkey's Politics -The Transition to a Multi-Party System. Princeton University Press, 1959.

Karslı, İbrahim H. "Çeviri Kuramları Açısından M. Hamdi Yazır'ın Çeviri Yöntemi." Kur'an Mealleri Sempozyumu -Eleștiriler ve Öneriler (April 24-26, 2003), edited by Hüseyin Yaşar et al, Diyanet Vakfi Yayınları, 2007, pp. 41-68.

Kazdal, İsmail. Serencam-Anılar. Pınar Yayınları, 2004.

Koskinen, Kaisa \& Paloposki, Outi. "Anxieties of Influence. The voice of the First Translator in Retranslation." Target vol. 27 no:1, 2015, pp. 25-39.

Massardier-Kenney, Françoise. "Toward a Rethinking of Retranslation.”, Translation Review, vol. 92, no.1, 2015, pp. 73-85.

McPherson, Eve. "Political History and Embodied Identity Discourse in the Turkish Call to Prayer." Music and Politics, vol.5, no. 1 (Winter), 2011, pp. 1-20

Ocak Gez, Başak. (2000). Bir Babıali Yayıncısının Portresi Tüccarzade İbrahim Hilmi Çı̆̆ıraçan. Toplumsal Tarih, 13 (February): 74.

Öztürk, Yaşar Nuri. Kur'an-ı Kerim Meali - Tüleşe Ceviri. Hürriyet Gazetesi, 1994.

Paker, Saliha. "Translation as Terceme and Nazire- Culture Bound Concepts and their Implications for a Conceptual Framework for Research in Ottoman Translation History." Cultural Transgressions. Edited by Theo Hermans. St. Jerome Publishing, 2002.

Sağlam, Bahaddin. Kur'an-ı Kerim ve Açıklamalı Meali. Tebliğ Yayınları, 2003.

Tahir Gürçağlar, Şehnaz. "Retranslation.” Routledge Encyclopedia of Translation Studies, 2nd ed., edited by Mona Baker \& Gabriela Saldanha, Routledge, 2009, pp. 233-236.

Üstün, Sema. A Historical and Conceptual Analysis of the Terms Used in the Titles of Turkish Qur'an translations since 1923 (With a Supplementary Bibliography of the Translations)". Unpublished MA Thesis. Bogazici University, 2013.

Wilson, M. Brett. "The Qur'an after Babel: Translating and Printing the Qur'an in the Late Ottoman and Modern Turkey." Ph.D. Dissertation, Duke University, 2009.

Venuti, Lawrence. "Retranslations: The Creation of Value." Bucknell Review, vol. 47, no. 1, 2004, pp. 25-38.

Yazır, Elmalılı Muhammed Hamdi. Hak Dini Kur'an Dili: Yeni Mealli Türkçe Tefsir. (1st volume), Diyanet İșleri Reisliği, 1935.

Yüksel, Edip. Mesaj: Kur'an Cevirisi. Ozan Yayınclık, 2000.

Zürcher, Erick. Turkey - A Modern History. Bloomsbury, 2004 